\title{
Thomistic Elements in Constructivism and Learner-Centered Teaching
}

\author{
John Vincent P. Ignacio \\ University of Santo Tomas
}

\section{Abstract}

The main purpose of this study is to present the philosophical underpinnings of Learner-Centered Teaching (LCT) using the philosophy of education of St. Thomas Aquinas and determine the possibility of how a philosophy of education can expand the limits of learner-centered pedagogies. LCT is a teaching pedagogy based on the theory of Constructivism. This paper is an attempt to give a philosophical standpoint to the practice of LCT so that LCT could expand its function in academic institutions from classroom scenarios to a more profound role in a learning environment. In a nutshell, this paper will discuss the nature and practice of LCT-the essential premises of this practice that yield specific teaching pedagogies. The focus of LCT will be on the Five Dimensions of LCT by Maryellen Weimer. For this attempt to be successful, a discussion of Constructivism logically comes first to present the main epistemological theories behind LCT that made it one of the most dominant and talked about teaching pedagogies in educational psychology.

After Constructivism and LCT have been presented, this paper will proceed to a discussion of the philosophy of education of St. Thomas Aquinas focusing primarily on commentaries on the Summa Theologiae and his De Veritate. Using Aquinas' theory, this paper will demonstrate the Thomistic elements of Constructivism in general and LCT in particular. Most criticisms 
on Constructivism and LCT are only based on psychology and psychometrics, thus making this study worthwhile in expanding the strengths and weaknesses of the practice of LCT based on a strong philosophical paradigm.

With the advent of the $\mathrm{K}$ to 12 Basic Education Program, the rise of Outcomes-Based Curricula, and the declaration of schools, colleges, and universities espousing learner-centered pedagogies, it is not enough for educators, especially philosophy teachers, to focus on the how and what to teach. An emphasis on the "WHY" of teaching and learning is a crucial reflection to determine the development of civilization. Nations prospered and declined due to the emphasis they have given to their education system. The role of philosophy in this setting is to become a critique of the current situation and, if it can, redirect the status quo towards a future that befits all. This paper is a humble contribution to a much larger goal. Using philosophy as a compass, education theories and pedagogies ought to be evaluated and re-evaluated to understand better the final outcome of teaching and learning.

\section{Keywords}

Constructivism, Learner-Centered Teaching, Outcomes-Based Curricula, philosophy of education 


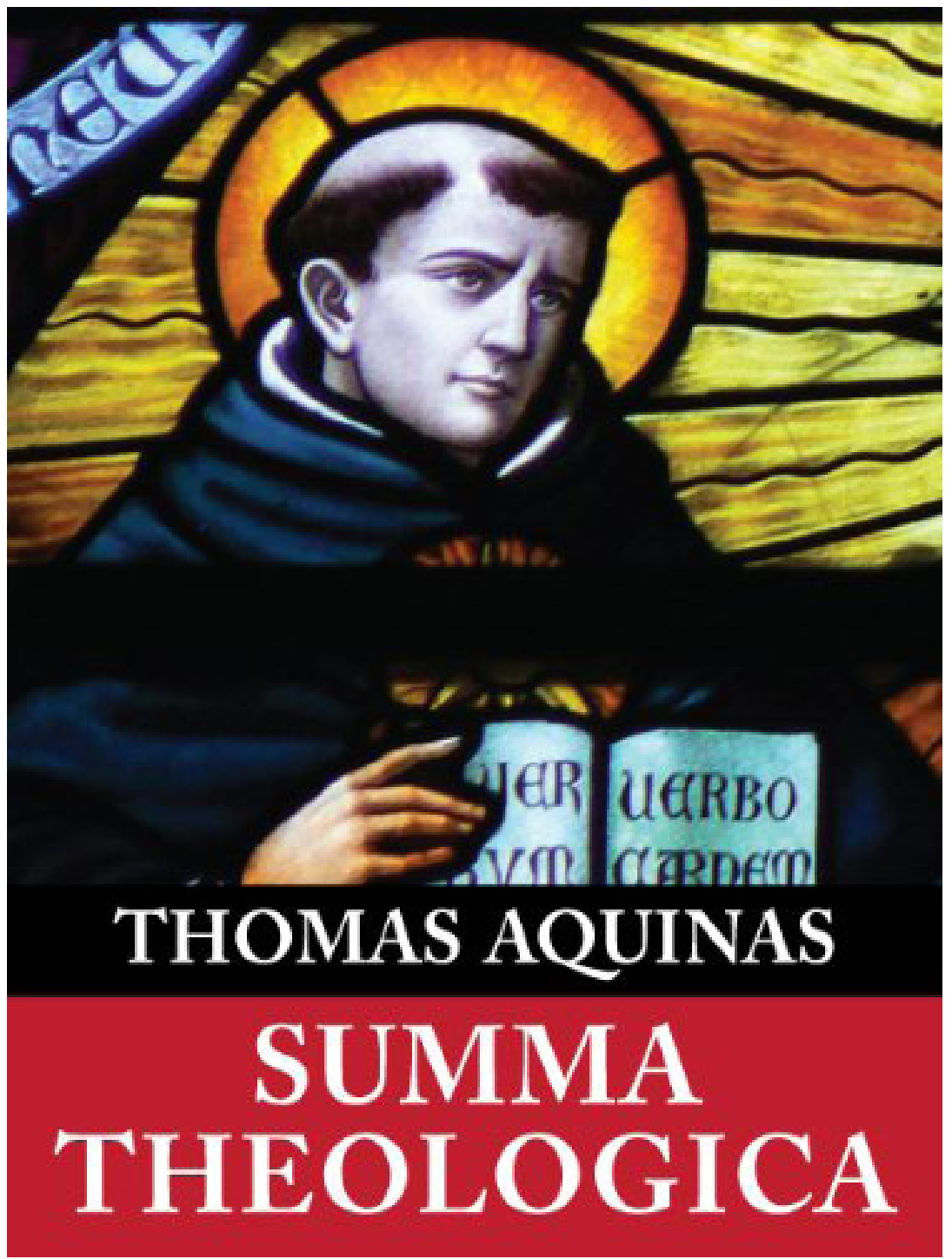

Fig. 1. Summa Theologica, the best-known work of the Angelic Doctor, St. Thomas Aquinas; https://www.amazon.com/ 


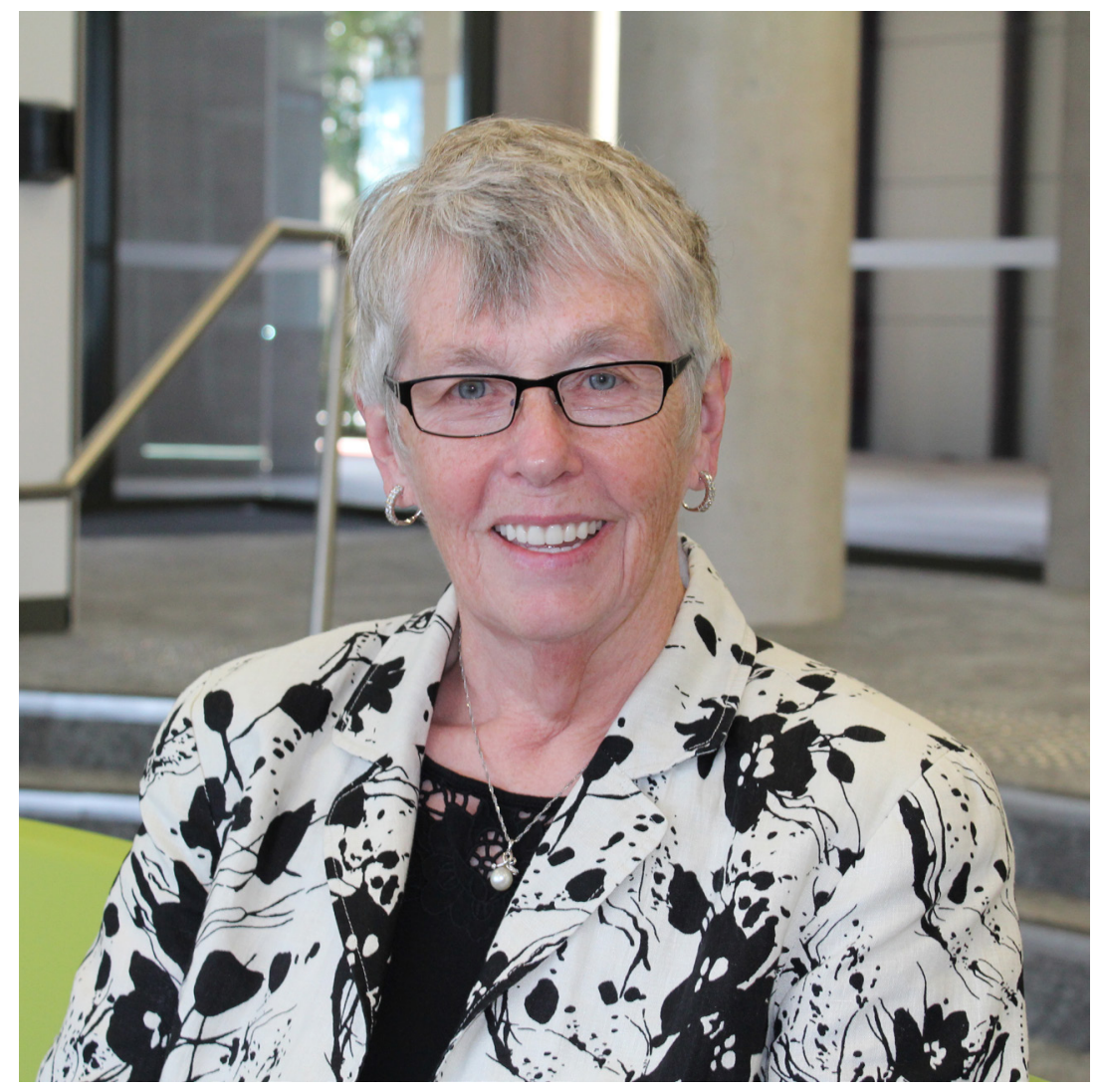

Fig. 2. Maryellen Weimer, author of Learner-Centered Teaching: Five Key Changes to Practice; https://www.usc.edu.au/ 


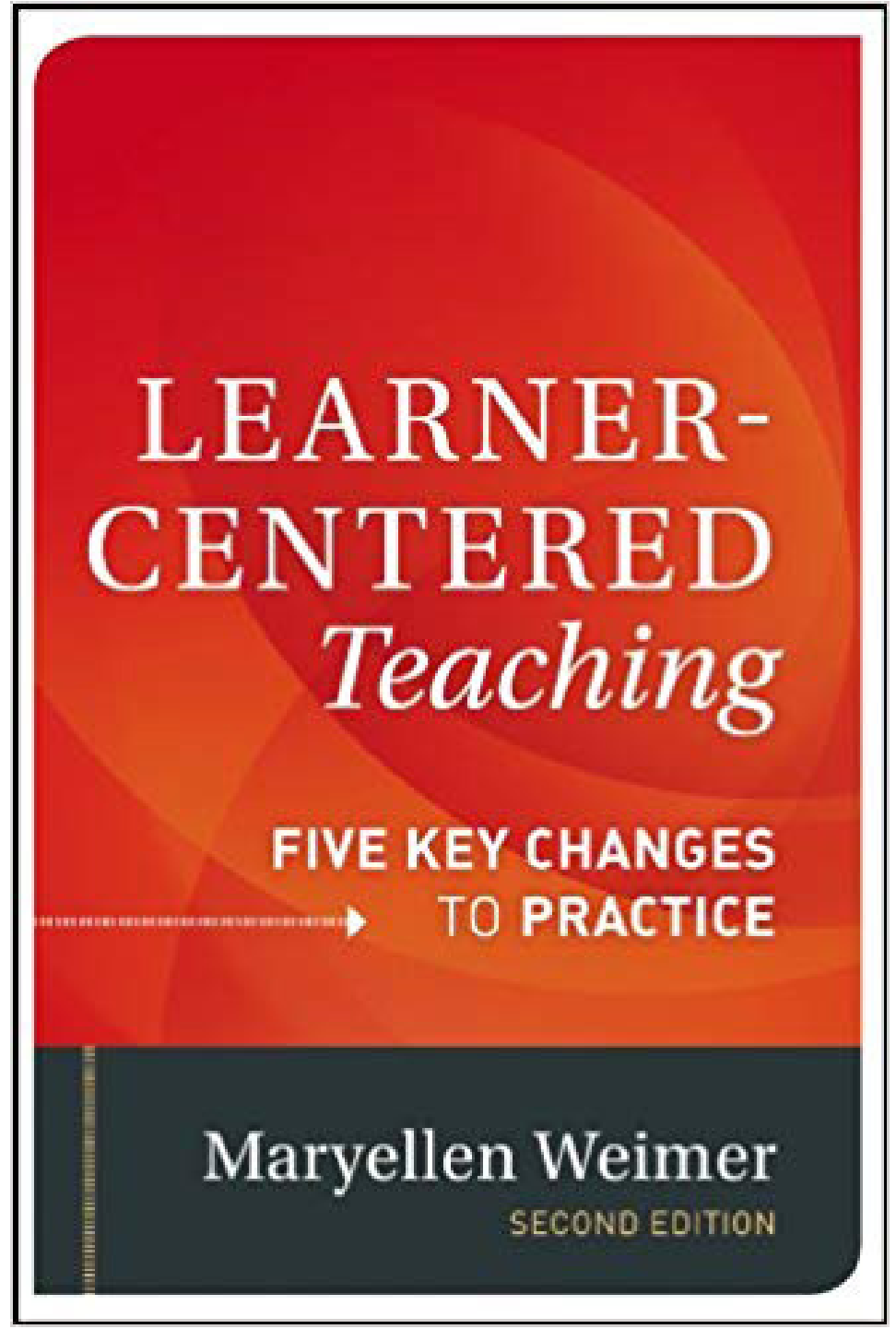

Fig. 3. Cover of Weimer's Learner-Centered Teaching: Five Key Changes to Practice, Second Edition, published bu Jossey-Bass; https://www.amazon.ca/ 


\section{Constructivism and the Pedagogy of Learner-Centered Teaching}

Learner-Centered Teaching (LCT) is a teaching practice or pedagogy following the tenets of Constructivism. LCT, therefore, is the application of Constructivism. The constructivist view is that knowledge claims are justified if we agree that they are useful in reaching our practical goalsrather than verified by proving that they correspond to reality (Colliver 49). As a learning theory, Constructivism shifts the paradigm of the teacher as the source or center of knowledge (objective) with that of the learner (subjective):

Constructivism in effect reverses the adage "knowledge is power" to say that "power is knowledge." The point is that knowledge is determined by social and political factors in addition to logic and reason, and even logic and reason are determined by social and political factors-further undercutting the idea of knowledge as an accurate representation of reality (Colliver 50).

Fox summarizes the elements of a constructivist stand point in learning:

(1) Learning is an active process; (2) Knowledge is constructed, rather than innate, or passively absorbed; (3) Knowledge is invented, not discovered; (4a) All knowledge is personal and idiosyncratic; (4b) All knowledge is socially constructed; (5) Learning is essentially a process of making sense of the world; (6) Effective learning requires meaningful, open-ended, challenging problems for the learner to solve (Fox 24).

To make meaning or sense to the world and making knowledge openended show the pragmatic and progressive elements of constructivism. As knowledge is constructed, it is constructed for the practical purpose of the learner-on how this knowledge can help the learner survive and progress in the world he/she lives in. These same reasons make constructivism attractive to societies geared for economic and social development.

Being learner-centered focuses attention squarely on learning: what the student is learning, how the student is learning, the conditions under which the student is learning, whether the student is retaining and applying 
the learning, and how the current learning positions the student for future learning (Weimer xvi). Being learner-centered in teaching means that the teacher should not just focus on the different content or skills that is being taught to the students, but also that the teacher needs to be mindful of the students' needs, prior knowledge, talents, interests, social orientation, linguistic abilities, and cultures (Brown 100).

Learner-centered teaching is opposed to the traditional teacher-centered approach. In LCT, the teacher ceases to be the source knowledge, and is transformed as a mentor or advisor. Learner-centered teaching emphasizes the students' intrinsic motivation to learn and the development of their abilities to acquire appropriate techniques in problem solving (Weimer, xvii). In addition, LCT utilizes the 14 Psychological Principles divided into four factors formulated by the American Psychological Association (1997), to wit:
A. Cognitive and Metacognitive Factors:
1. The Nature of the Learning Process
2. Goals of the Learning Process
3. Construction of Knowledge
4. Strategic Thinking
5. Thinking About Thinking
6. Context of Learning

\section{B. Motivation and Affective Factors:}

1. Motivational and Emotional Influences on Learning

2. Intrinsic Motivation to Learn

3. Effects of Motivation on Effort

C. Developmental and Social Factors:

1. Developmental Influences on Learning

2. Social Influences on Learning

D. Individual Differences Factors:

1. Individual Differences in Learning

2. Learning and Diversity

3. Standards and Assessment 
In a successful LCT strategy, it is not required that all these 14 principles are immediately followed in the entire duration of a class session. However, the APA strongly suggests that these principles ought to be the guide for teachers in making their strategies learner-centered.

Learner-centered environments are designed to help students make connections between previous knowledge and newly acquired knowledge (125). LCT focuses on the learning process more than the content of learning. To make knowledge meaningful for the learner, LC educators place the condition of the learner in forming new knowledge. As pressure continues to mount on teachers to ensure the students' success in learning, many different approaches to teaching are being recommended (Brown 104). Learner-centered environments provide a wide array of teaching styles that can address the diversity of learners.

Sharon Colley follows Barr and Tagg (1995), Doyle (2008), Fink (2003), Gardner (1994) and Weimer (2002) in stating that learner-centered approaches to education have been shown to lead responsible, active learners who demonstrate higher levels of achievement than those taught with traditional teaching methods (229).

Much has been said about LCT, but the question remains, as a practice of teaching: "How is LCT done?" Weimer in her groundbreaking book, Learner-Centered Teaching: Five Key Changes to Practice, states that there are Five Dimensions of transforming Traditional Teaching to Learner-Centered Teaching: The Balance of Power, the Function of Content, The Role of the Teacher, Responsibility of Learning, and Purposes and Processes of Evaluation.

\section{The Balance of Power}

When teaching is learner-centered, power is shared rather than transferred wholesale (Weimer 28). In LCT, the teacher still controls the key elements of the learning process considering that he/she is the expert or the master of the content that is to be taught. However, in LCT, some of the elements in the learning process can be shared or transferred to the learners. By doing so, a learning environment that is safe for the learners is created, and the 
learners become more active and responsible players in the learning process. The goal of balancing power is to equip the students with learning skills so sophisticated that they can teach themselves (Weimer 29).

By balancing the power scheme in the classroom setting (or laboratory), students develop higher confidence and become more motivated in participating in the learning process. According to Weimer, the sharing of power does not only benefit the learner, but the faculty members as well because this promotes more active and responsible students in the class. When power is shared, every member of the class, including the teacher, becomes co-owners of the knowledge gained in every session:

Learner-centered instruction involves a reallocation of power in the classroom. It requires that faculty give students some control over those learning processes that directly affect them. And this reallocation does require a change (45).

\section{The Function of Content}

A lot of educators are very much focused on the content of the course or subject that they are teaching. The reason is simple-students need to know the things in the course or subject because the test will focus on the content of the course or subject. This is very much evident in the licensure examinations that most countries conduct. Most examinations are about content; hence, the natural tendency of educators is to focus on the content of the course. But how much content is enough?

Strong allegiance to content blocks the road to more learner-centered teaching (Weimer 46). Educators who focus too much on content end up with students knowing things that are not significant for them. At most research universities and in some other types of institutions, the faculty can commit many pedagogical sins and find forgiveness so long as their course has rigor and standards (Weimer 47). In a traditional instructor-centered course, the focus is on covering the content and helping students to build a knowledge-base, or use content to solve problems, or both (Blumberg 73). So, content-based instruction is not necessarily bad; it can give students 
a large knowledge foundation that can actually be useful in their future careers. However,

[t]he learner-centered instructor helps the students engage with the content and apply the material, in addition to building a knowledge base. Learnercentered instructors help the students learn why they need to know the content, convey an appreciation of the value of content to students, and help them learn new content in the future (Blumberg 73).

So, in a learner-centered environment, covering the content is not the focus. The content is also used for other functions to improve the student's learning skills.

\section{The Role of the Teacher}

When power is shared and when the functions of the content vary, it is a logical necessity to posit that the role of the teacher will also change. Instead of being the source of knowledge, the teacher becomes a facilitator of knowledge. The learner-centered teaching role has been compared to that of a guide (Weimer 75). As a guide, the teacher allows the students to discover for themselves the knowledge that they need to know. There are other metaphors to define the role of a teacher in an LC environment: a coach, a maestro, and even a midwife. The reason that these roles work is simple and obvious: when the focus is less on teaching and more on learning, learning is not assumed or presumed to happen automatically (Weimer 77).

\section{The Responsibility of Learning}

Since LCT focuses more on the learning compared to traditional teaching styles, not only the role of the teacher changes but so too with the burden of responsibility for the learning process. In LCT, more responsibility is given to the learners. This involves developing the intellectual maturity, learning skills, and awareness necessary to function as independent, autonomous learners (Weimer 95). Weimer further notes: 
When teaching is learner-centered, the classroom climate changes in ways that accomplish two objectives. First, faculty aim to create a climate conducive to learning, meaning that they work to establish an environment that positively affects how much and how well students learn. Second, faculty aim to create environments where without (or fewer) rules and requirements, students do what they need to learn effectively, develop themselves further as learners, and act in ways that support learning efforts of others (99).

Student participation in the learning process is essential in LCT. It is the students themselves who will give meaning to the knowledge they construct. Brown follows McCombs (2001) and Stroh and Sink (2002) in observing that, in learner-centered classrooms, students must be actively involved and they must be provided with opportunities for hands-on learning. They must be allowed to act on their environments and construct their own knowledge (Brown 101).

\section{The Purpose and Processes of Evaluation}

In traditional teaching styles, more often than not, assessment methods are used to test the students' knowledge of content, on how much they can remember what is instructed to them. Grades play a huge role in student assessment simply because teachers are required to submit grades. In this mindset, students' learning is not really being measured. However, learner-centered teaching does not deny the importance of ascribed grades (Weimer 119). But the focus should not be on the grades per se.

In learner-centered teaching, assessment is made of learning and for learning. In a nutshell, assessment methods can be utilized to help in the learning process and not simply to make grades. Moreover, different assessment methods such as graphic organizers, reflection papers, role playing, project-based activities, aside from the traditional pen and paper tests can address the different learning styles of students and provide a wider range for assessment and evaluation. 
In an LC environment, assessment is not only the responsibility of the teachers but also of students. Evaluative assessment can be used to motivate students to do better and improve their skills and mastery of the content.

\section{St. Thomas Aquinas on Teaching and Learning}

Aquinas as a teacher was very much like most of us present-day educators. He had a class where he had students who sat down awaiting instruction on philosophy and theology. As Davies puts it, Aquinas' job was to teach people face-to-face (631). Though primarily Aquinas was a theologian, he saw the importance of philosophy in enlightening the mind towards Divine Knowledge. Though Aquinas spent most of his time in his different treatises and of course in writing his magnum opus, we can imply that he understood the needs and challenges of teachers in the process of instruction.

Aquinas' philosophy of education can be seen in his different writings. Unlike other philosophers of education like Rousseau, Dewey, and Freire, Aquinas did not write one singular treatise on his ideas about education. One must also look at his Summa Theologiae, De Veritate, and some of his different commentaries on different issues or topics.

\section{On the Possibility and Purpose of Teaching}

Commentators on Aquinas regarding his idea on teaching seem to converge on this first question, "Can anyone teach?" The reason for this question, though we might find this strange to ask, is that Aquinas quotes a passage from the Gospel according to Matthew (23:8): "You are not to be called rabbi (teacher), for you have one teacher and you are all students." This passage was significant for Aquinas for the simple reason that for him, education is geared towards moral theology. Davies explains why Aquinas wrote the Summa Theologiae:

Moral Theology is at the center of work (Summa), but not as if in a vacuum. It is presented by Aquinas with a work-up to it in which he writes about the nature of God, the nature of human being as things falling under God's providence, and human perfection in general (633). 
Hence, Aquinas posited this inquiry in Question 1 of his De Veritate and in Article 1 of Question 117 of the Summa Theologiae: Is it possible for one person to teach moral theology to another? This question, in fact, is a pedagogical one as much as it is epistemic. By citing the Gospel according to Matthew, Aquinas implies that only God can teach if we consider teaching as to one causing someone to gain knowledge. Davies quotes Aquinas in De Veritate:

Teachers do nothing to their pupils save to put certain signs before them which signify something either by words or gestures. Now one cannot teach others, causing knowledge in them, by putting certain signs before them. For either one proposes signs of objects that are already known objects, then the ones to whom the signs are put already have the knowledge and so do not acquire it from the master; if they were unknown objects, they cannot learn anything at all from them (634-635).

So, if God can be the only one to teach, if teaching is to cause knowledge to someone, what happens now to human teachers? Vivian Boland provides a twofold answer to this dilemma:

One important distinction, he (Aquinas) says, is that between principal and instrumental causes. An instrumental cause is efficacious in producing the effect it does only because it is within the power of the principal cause. A pen may be said to write but only because it is in the hands of the writer. It is always to the principal cause that the effect is attributed even when an instrument is used. In this sense, God alone as principal cause can be said to teach but the instrumental cause may also be said to teach while acknowledging that its contribution to the effect is completely within the power of the instrumental cause ("Truth, Knowledge and Communication" 289).

As the pen is to a writer that cause the writing, the teacher is to God that causes knowledge. Aquinas sees the teacher as an instrument in fulfilling God's ultimate goal for man. As it is common knowledge for students of philosophy, Aquinas was strongly influenced by Aristotelian philosophy when it comes to the teleological aspects of man. The teacher, therefore, must be consistent in using his/her skills in bringing knowledge of God to 
the learner, as God is man's ultimate happiness. The teacher, then, participates in the learning process by which the learner gains from God as God is the source of knowledge and wisdom. Secondly, Boland writes:

A human being can teach in these ways, by presenting something immediately intelligible, and so leading (ducens) a person to knowledge, and by bringing (manuducatur) the learner from what he knows already to what he then comes to know. Such teaching among human beings, is not by way of illumination as it is among angels, but by way of speaking (per modum locutionist) ("Truth, Knowledge and Communication" 290).

Boland's second point emphasizes the primary idea that teachers are not sources of knowledge but rather instruments by which the learner forms knowledge. The general idea behind this argument is that students can only learn if they already know somehow what words signify, in which case they are not really learning when their teachers talk to them or present them with illustrations or examples and the like (Davies 635).

Based on the following points, i.e., 1) teachers are instruments of learning and 2) students' pre-knowledge of things, we can conclude that the entire learning process is a responsibility not only of the teacher but also of the students. Students must contribute to their learning by bringing some knowledge with them as they are schooled, while the teachers can lead people to further knowledge by presenting them with certain data, with new things to consider, and by drawing their attention to logical consequences and connections that students might not have been able to notice on their own (Davie 636).

As a theologian, Aquinas made clear that moral theology is the ultimate end of education thus, Davies says that the Summa Theologiae is a treatise which tries to present Christian teaching and to locate moral theology accordingly (633). This theological dimension is articulated in the opening paragraphs of the Summa Contra Gentiles where Aquinas says that the ultimate end of the whole universe is Truth and this is also the aim of the wise (Ozolins 10). All the different disciplines and sciences, for Aquinas, are 
geared towards one particular end, and that is Truth. Teaching, as an art, is also for the ultimate purpose of attaining Truth.

\section{On the Process of Teaching and Learning}

To be very clear, the teacher for Aquinas is not the source of knowledge but an instrument by which knowledge is formed by the learner. So, we then posit the question, how does one teach? As a scholastic, Aquinas followed the standard practices of the medieval universities: reading (lection), disputation (disputation), and oral repetition (repetition or praedicatio) (Boland, The Healing Work of Teaching 35). This kind of method of instruction is still very much present today. Teachers assign reading materials or texts to be read by the students, which is followed up by a class discussion that culminates with some form of an assessment wherein the main points of the topic are repeated. In Aquinas' time, master and students engaged secondly in disputations where questions were considered dialectically, and positions were refined through the presentation of evidence and in the progress of logical argument (Boland, The Healing Work of Teaching 36).

The class set-up which Aquinas probably sued was a three-step methodthat of reading, dialogue, and repetition. But Aquinas stresses that it is in the second step that the best teaching is done rather than the first. Boland compared the format of the dialogue of the Summa Theologiae to that of other works in dialogue form like those of Plato and Boethius. According to Boland, the arguments that were presented in the Objections in the Summa Theologiae were real arguments. So, even when written down, his way of learning and teaching is dialectical (Boland, The Healing Work of Teaching 37).

This dialectical process of the teaching-learning activity cannot be achieved without certain conditions. First, a teacher who loves his/her subject and who is enthusiastic is far more likely to capture and retain the attention of the learner than those who show no commitment to the educative task (Ozolins 11). Though we have admitted that the teacher is an instrument of learning, the teacher still affects the learning process. Aquinas really does think that teachers can make a difference to people in helping 
them to come to know what they did not previously grasp (Davies 636). Aquinas did use the term doctor to mean teacher, probably to emphasize the deep passion of the teacher towards the subject he/she is teaching. A teacher is required to have mastery of his or her content to deliver the best form of dialectic with his/her students.

The second condition pertains to the student. Ozolins writes:

The pupil, on his or her part, begins by having faith that what the teacher is about to impart is trustworthy and that the teacher is knowledgeable about the subject. Faith is required not just for religious belief, but for scientific understanding as well, for as Aquinas says, we could not live in the world at all unless we are prepared by faith (11).

Aquinas emphasizes the necessity of trust and faith in the teaching-learning activity, thus underscoring the importance of the relationship between the learner and the teacher. The teacher needs to be sincere in his/her role to connect with the learner; to make the relationship distant between pupil and master will not facilitate learning. By having faith in the teacher, the student develops trust and opens himself/herself to the learning process thus developing in him/her the love for learning. The educative process as Aquinas sees it is one which enables the relationship between the teacher and the student to facilitate learning (Ozolins 11).

Aquinas follows Aristotle in this idea of relationship existing between the teacher and the student. Aristotle's concept of Friendship of the Good is the best circumstance by which the learning process can fully bloom. It is when the teacher and the student both work together to attain certain truths that true learning is produced.

\section{On Knowledge and Truth}

Aquinas' idea on human knowledge follows strongly from Aristotle's in which human has the capacity to grasp the essences of things through abstraction. Since man is a composite of body and soul, of matter and substantial form, man has the innate capacity to learn both the accidental and substantial features of things. However, the realities we are best equipped to know are 
the realities of this world that are susceptible to empirical investigation and are capable of being rendered intelligible (Boland, St. Thomas Aquinas 59). However, all knowledge must develop from the data of sensuous perception, and it is only through inferences and indirectly that it can rise to immaterial notion concerning the immaterial world (van Becelaere 617-618).

Aquinas' epistemology is grounded on both psychology and metaphysics. Psychologically, knowledge is formed through the senses and is abstracted by the intellect. In this area, the forming of knowledge is indeed in accordance to the knower: by the perfection of his/her senses and by the capacity of his/her intellect. Whatever is received, is received according to the mode of the receiver. On the other hand, Aquinas' epistemology is also deeply grounded on his metaphysics. Aquinas holds that all being are a composite of matter and substantial form. The substantial form of things is that which allows things to be known and for man to know. But there is a far greater Metaphysical concept in Aquinas' epistemology, i.e., Truth. However, Ozolins reminds us that:

despite the apparent acknowledgement that to some extent knowledge is constructed, Aquinas rejects a relativist view of knowledge and argues that human beings can discover the truth about the nature of the world and of themselves. That is, Aquinas rejects the view that individuals construct knowledge which is idiosyncratic, since the quest for knowledge is the quest for truth and whether something is true or not is not determined by individual whim (12).

Aquinas was a realist in that he believes that there is truth about the world and that the human being is equipped to discover it (Boland, St. Thomas Aquinas 63). Thus, Truth, Veritas, is something that Aquinas holds to be Absolute and Universal. Truth is linked with being as one of being's Transcendental Properties (Unum, Bonum, Verum). Apart from Unum, Bonum and Verum (Good and True) are defined in a positive way. The Good refers to the soul corresponding to the soul's powers and apprehension; and the True refers to soul's coinciding with all being through the power to apprehend 
(Boland, St. Thomas Aquinas 64). Therefore, if Knowledge is only knowledge if it is true, it can be equated that knowledge is also that of the Good.

\section{Thomistic Elements in Constructivism \& Learner-Centered Teaching}

Before proceeding to the Thomistic elements found in Constructivism and LCT, let us first present the main principle that is not found in Constructivism and LCT. By doing so, we can focus on the main topic of this paper with much clarity and rigor.

As stated in the first part of this paper, Constructivism (and LCT by implication) does not adhere to claim any metaphysical foundation of knowledge. The concepts of the Absolute and Universal which are inherent in Thomistic philosophy cannot be found in the tenets of Constructivism. Constructivism is not an epistemological theory that requires a metaphysical foundation; rather Constructivism is a Learning Theory in which knowledge is said to be justified rather than deemed to be true or false or verified against a metaphysical principle. With this distinction out of the way, let us proceed with the main issue.

To present the Thomistic elements in Constructivism, we shall use Fox's (2011) summary of the elements of a constructivist standpoint in learning:

1. Learning is an active process. This element of Constructivism is also found in Aquinas' principles of learning and teaching. Aquinas strongly affirms that the dialectic approach is far better as a teaching strategy than mere reading. Secondly, Aquinas presents that the student and the teacher form a mutual relationship to actively engage in the learning process.

\section{Knowledge is constructed, rather than innate, or passively} absorbed. With certain limitations, Aquinas presents the same principle. Knowledge is constructed in as much as the learner forms his understanding of things through the assistance of the teacher, but idiosyncratic constructs of knowledge for Aquinas is absurd. Just as a teacher participates with God in the teaching, so does the student participate with the teacher in the learning process. 
3. Knowledge is invented not discovered. Again, with certain limitations, Aquinas probably will also accept this principle. Knowledge is in a way invented in as much as the teacher must invent and reinvent methodologies to assist the learner in the learning process. But it is not in a way that a learner invents knowledge from nothing, for only God can do so ex nihilo. Since for Aquinas Truth is something universal and absolute, knowledge is discovery of such truths. But we might, with limitation say that the process by which we learn is an invention or reinvention of the teaching-learning activities.

4a. All knowledge is personal and idiosyncratic. In the first case, Aquinas supports this principle as the learner forms his/her understanding of things. Knowledge is personal because the student brings with him/her his/her own prior-knowledge of things that allows him/her to discover things he/she did not know. But the second case is unacceptable for Aquinas. As stated above, there exists Absolutes and the Universal in Aquinas' metaphysics.

4b. All knowledge is socially constructed. Again, with certain limitations, this might be acceptable for Aquinas. Aquinas points out that learning in the classroom setting involves the interaction of the teacher with the students and the students with each other, thus creating a social setting by which learning is facilitated. However, Aquinas also presents that knowledge can be obtained by meditative and contemplative exercises of an individual wherein truth is revealed to him by God through Faith.

5. Learning is essentially a process of making sense of the world. Learning for Aquinas is a movement from potentiality to actuality as part of man's ultimate end. Aquinas postulates that the end of education is moral theology, in which man attains knowledge of the Absolute through reason and faith. Learning, therefore, makes sense of the world for man because it allows man to move closer to the Divine.

6. Effective learning requires meaningful, open-ended, challenging problems for the learner to solve. Using the Summa Theologiae as a primary example, Aquinas presents the idea that the teacher ought to present the issues or topics that are relevant and significant to the learner. 
The format of how the Summa Theologiae was written presents a discourse of ideas and concepts by which the learner investigates, with the guidance of the teacher, the necessary truths implied in the learning process.

To present the Thomistic elements of LCT, we shall use Weimer's (2002) Five Dimensions of Learner-Centered Teaching:

1. The Balance of Power. As presented above, Aquinas does not see the teacher as the source of knowledge in the learning process. Instead, Aquinas argues that the teacher is an instrument of God in forming knowledge in people. The teacher's duty is to provide guidance, mentorship and instill morality in the student. The student is not to be considered a tabula rasa but is gifted with powers and capabilities for him/her to grasp knowledge. The learning process for Aquinas is a tripartite activity between God, the teacher, and the student.

2. The Function of Content. Aquinas argued that learners should not be over burdened with so much ideas or theories. Aquinas observes that students are reading too much philosophical and theological text but does not help the student attain the ultimate purpose of education. Aquinas wrote the Summa Theologiae so that learners may be able to contextualize his learning to bring about a more organized understanding of things. Thus, Aquinas promotes the importance of the learning process more than the content of what is being learned. This is consistent with LCT.

3. The Role of the Teacher. This concept is probably where Thomistic philosophy and LCT strongly converge. In both LCT and Thomistic Philosophy, the teacher is viewed not as a source of knowledge but as an instrument to facilitate learning. Both Aquinas and LCT promote the idea that teachers are supposed to be mentors, guides, and midwives who assist the learner in the formation of knowledge.

4. The Responsibility of Learning. In LCT, the students are expected to develop an internal motivation to enhance learning. In like manner, Aquinas posits that the learner must have faith and openness for him/her to be guided in the learning process. Also, both LCT and Aquinas agree that teachers ought to have mastery of the subject that he/she is teaching to effi- 
ciently guide the learner. Both teachers and students are expected to form mutual trust and friendship, passion and desire for learning, and to have a strong moral foundation as learning progresses.

5. Purpose and Processes of Evaluation. At this point, Aquinas is silent for the simple reason that in medieval times, the same assessment tools that we use today were not available. However, it may be safe to say that Aquinas would agree to use evaluation tools as instruments for learning since the teacher is expected to find ways and methods to make the facilitation of learning effective and efficient, meaningful and purposeful, and morally sound.

\section{Conclusion}

The purpose of this paper has been to present some elements of Thomistic Philosophy in a postmodern theory of education. It does not suggest that Constructivism and LCT have their roots in Thomistic Philosophy. Aquinas and the proponents of Constructivism and LCT are centuries apart; in fact, we might not fully comprehend how the ideologies of teaching and learning have evolved throughout this time. However, the third part of this paper has made it clear that there are elements of Thomism found in the tenets of Constructivism and LCT. But what does this prove?

First, it proves that Aquinas was ahead of his time. The findings of this paper show that Aquinas has not limited himself only to the philosophical discussion of metaphysics, epistemology, ethics, and theodicy for which he is well-known in the world of philosophical discourse; but his ideas about education, teaching, and learning have relevance and significance in our postmodern times.

Secondly, this paper has shown that there is truly a need to revisit theories of education and ground them on philosophical precepts to develop a theory of education suited for our needs in this society. Theories of education rely heavily on psychology, sociology, and political perspectives; but Aquinas presents us with metaphysical and moral foundations for learning. 


\section{Implications}

Learner-centered teaching promises to produce dynamic, engaged, and independent learners. However, as pedagogy, LCT is constrained within the classroom setting. LCT uses psychological principles backed-up by psychometrics to show proof of transformative or meaningful learning using varied forms of teaching styles, classroom activities, and assessment tasks. The constraint of LCT within the classroom is essentially within its main purpose; but if we look at the education system, LCT practices may be in peril if learning institutions do not create the necessary learning environment consistent with what is being produced in learner-centered classrooms. Learning is a social process, and the classroom ought not to be the only social medium for learning in schools.

Most learning institutions, even in higher education, are organized within a hierarchical structure that limits, or even prevents, the democratization of learning. There is a false assumption that is probably in the minds of people that education is concentrated within the four walls of the classroom; on the contrary, real and meaningful learning happens in actual real-life experiences. Therefore, it is not enough to transform the classroom setting into one that is learner-centered; it is now necessary to transform the entire learning institution (as a whole) into learner-centered. But learner-centered principles alone cannot take on this task of transforming institutions since it is neither normative nor prescriptive.

Here we find the value of Aquinas' concept of education. First, for Aquinas, education's primary goal is moralization. Though Aquinas looks at moralization within Catholic concepts, we can at least safely posit that for Aquinas, moral actions come from a person's intellect and free will. Therefore, institutions of learning (especially in higher education) should allow the nurturing of the students' intellect and will for them to be engaged more in the schools' functions such as policy-making, financial decisions, and student welfare. If schools remain orthodox and hierarchical, the engagement process becomes limited or even suppressed limiting the students' ability to maximize the potentials of their intellect and will. LCT practices produce students who are supposed to be active learners; it is now 
therefore the moral responsibility of schools to allow these active learners to have meaningful and transformative engagements within the entire learning community.

Secondly, Aquinas emphasized the need for dialogue in the learning process. Consequently, dialogues ought not to be constrained in the classrooms, but rather it must be expanded within the learning community. The moralization of education in schools is best practiced, in my opinion, through developing a culture of dialogue in the institution and not by the imposition of rules and regulations by authorities. Aquinas himself investigated different perspectives from the ancient Greeks to the Arab thinkers when he wrote the Summa; he presented their thoughts, challenged them, and gave his own answers to the questions at hand. Learning today is no longer discipline-based; learning is interdisciplinary and contextual making it reasonable to assert that institutions of learning promote this concept within the learning community.

Learner-centered pedagogies are indeed promising and can produce better citizens capable of improving society in the future. Developing our education system should not just be about looking at education within the microcosmic structure of the classroom; we also need to expand its development within learning communities such as schools, colleges, and universities so that eventually, the development of the system itself may come to fruition. This is a huge task, and it will take time and a lot of effort to do so. But the first and most crucial step is to open ourselves up to the possibility of grounding learner-centered pedagogies on a philosophy of education such as that of St. Thomas Aquinas. 


\section{Works Cited}

American Psychological Association's Board of Educational Affairs. Learner-Centered Psychological Principles: A Framework for School Reform and Redesign. APA, 1997.

Blumberg, Phyllis. Developing Learner-Centered Teaching: A Practical Guide for Faculty. Jossey-Bass, 2009.

Boghossian, Peter. "Behaviorism, Constructivism and Socratic Pedagogy. Educational Philosophy and Theory, vol. 38 no. 6, 2006, pp. 713-722.

Boland, Vivian. "Truth, Knowledge and Communication: Thomas Aquinas on the Mystery of Teaching." Studies in Christian Ethics, vol. 19 no. 3, 2006, pp. 287-304.

---. St. Thomas Aquinas. Bloomsbury Academic, 2007.

---. “The Healing Work of Teachings: Thomas Aquinas and Education.” Dominican Approaches in Education: Towards the Intelligent Use of Liberty edited by G. Kelly \& K. Saunders. ATF P, 2007, pp. 32-41.

Brown, David M. "Learner-centered conditions that ensure students' success in learning." Education, vol. 124 no. 1, 2003, pp. 99-107.

Colley, Sharon L. "Implementing a Change to a Learner-Centered Philosophy in a School of Nursing: Faculty Perceptions." Nursing Education Perspectives, vol. 33 no. 4, 2012, pp. 229-233.

Colliver, Jerry A. "Constructivism: The View of Knowledge That Ended Philosophy or a Theory of Learning and Instruction?” Teaching and Learning in Medicine, vol. 14 no. 1, 2002, pp. 49-51.

Davies, Brian. “Aquinas on Teaching and Learning.” New Blackfriars, vol. 94 issue 1060, 2014, pp. 631-647.

Fox, Richard. "Constructivism Examined." Oxford Review of Education, vol. 27 no. 1, march 2001, pp. 23-35.

Ozolins, Janis Talivaldis. "Aquinas and his Understanding of Teaching and Learning.” Aquinas, Education and the East, Springer, 2013, pp. 9-25.

Turner, Steven L. "Student-Centered Instruction: Integrating the Learning Sciences to Support Elementary and Middle School Learners." Preventing School Failure, vol. 55 no. 3, 2011, pp. 123-131.

van Becelaere, F. "A Summary Exposition of Saint Thomas Aquinas's Philosophy of Knowledge.” The Philosophical Review, vol. 12 no. 6, 1903, pp. 611-628.

Weimer, Maryellen. Learner-Centered Teaching: Five Key Changes to Practice. JosseyBass, 2002. 